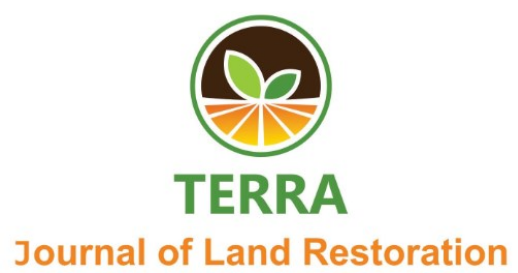

\title{
Effects of Planting Density and Weeding Frequency on the Corn Growth and Yield in Intercropping System with Peanut
}

\author{
Welmi Samita ${ }^{1}$, Edhi Turmudi ${ }^{1 *}$, Sigit Sudjatmiko ${ }^{1}$, Widodo Widodo ${ }^{1}$ \\ ${ }^{1}$ Agroecotechnology Department, University of Bengkulu, Bengkulu, 38121, Indonesia \\ email : edhiturmudi@gmail.com
}

\begin{abstract}
The research aimed to determine the optimal population ratio at each frequency of weeding for the growth and yield of maize. It was carried out from February to May 2020 in the field. There are 2 treatment factors tested arranged in a splite plot design, which was repeated 3 times using a completely randomized block design (CRBD). The first factor is the frequency of weeding as the main plot (Main Plot) consisting of no weeding, $1 \times$ weeding (21 DAS), $2 x$ weeding (21 DAS and $42 \mathrm{DAS}$ ). The second factor is the ratio of the population as sub-plots, consisting of $100 \%$ corn $+0 \%$ peanuts, $80 \%$ corn $+20 \%$ peanuts, $60 \%$ corn $+40 \%$ peanuts, $40 \%$ corn $+60 \%$ peanuts, $20 \%$ corn $+80 \%$ peanuts. The results showed that the growth and yield of maize in the intercropping system with peanuts gave the same response to the population ratio at all weeding frequencies. The planting density of $40 \%$ maize $+60 \%$ peanuts produced the highest response on the variables of stem diameter $(24.675 \mathrm{~mm})$, plant fresh weight $(667.51$ grams) and biomass weight (79.924 grams). While the highest response to weeding frequency was 2 times (21 DAS and 42 DAS) only on plant fresh weight (588.08 grams).
\end{abstract}

Keywords : planting density, weeding frequency, intercropping system

\section{INTRODUCTION}

Corn (Zea mays L.) is the second food crop after rice, which is used as a staple food because the source is carbohydrates, fats and proteins which are important for public health for some Indonesians. In addition, corn also contains dietary fiber that the body needs, and is rich in essential fatty acids, isoflavones, minerals $(\mathrm{Ca}, \mathrm{Mg}, \mathrm{K}, \mathrm{Na}$, $\mathrm{P}, \mathrm{Ca}$ and $\mathrm{Fe}$ ), anthocyanins, beta-carotene, and others (Suarni \& Yasin, 2011). In addition, corn has many functions, including: for food, feed, raw materials for the fuel industry, raw materials for the fiber industry, as well as for animal feed ration, especially for poultry, corn is the main component with a proportion of around $60 \%$. It is estimated that more than $58 \%$ of domestic maize needs are used for feed, while for food only about $30 \%$, and the rest for other industrial needs and seeds (Kementerian Pertanian, 2020).

Intercropping is a polyculture planting system by planting two or more types of plants in regular rows and alternating within the same or nearly the same period of time on a plot of land (Ratri et al., 2015). The condition for a good intercropping is that the two plants that are intercropped do not have the same growth period, if the growth period is almost the same, the growth phase is different, the need for water, light, and nutrients is also different, besides that it must have roots, canopy area and plant height. different and has no allelopathic effect on intercropped plants (Setiawan, 2009). According to Wibowo (2009), intercropping is intended to efficiently utilize the environment (nutrients, water and sunlight) in order to obtain maximum results. Intercropping can be done between seasonal crops and seasonal crops that are mutually beneficial, for example between corn and beans (Nurmas, 2011). The combination of the right types of plants in the intercropping system, each type does not experience pressure in interaction. This can be seen from the relative yield value (RYij), namely the comparison value of crop yields in the intercropping system compared to crop yields in the monoculture system with RYi = Yij / Yii (Beets, 1982).

The emergence of weeds on cultivated land is generally unavoidable, and this is an important 
problem because it can inhibit growth and reduce crop yields. Therefore, the emergence of weeds must be controlled properly before the decline in crop yields occurs. The results of research by Dinata et al., (2017) showed that weeding 21 DAS (day after sowing) and 42 DAS resulted in the highest growth and yield of maize plants. Likewise, weed control in the intercropping system between peanuts and cassava which is carried out at the age of 14 DAS and 28 DAS also gives the highest crop yields (Hardiman et al., 2014). Meanwhile, according to research Sena et al. (2018) weeding at 14, 28 and 42 DAS in the intercropping land of sweet corn and peanuts is more effective in controlling and suppressing weed growth. From the research results, Fadhillah et al. (2018), the frequency of weeding had a significant effect on the increase in the size of the parameters for the number of leaves, stem diameter, ear length, and weight of maize cobs.

Efforts to increase maize yield through the double cropping system can be constrained by competition between similar and different types of plants. To avoid competition, it is necessary to arrange an appropriate population ratio so that the two plants can grow well. Apart from competition between corn and peanut crops, competition also occurs with weeds. The emergence of cropping systems can reduce crop yields if not controlled properly. The appropriate frequency of weeding must be determined so that the presence of weeds does not become a strong competitor for maize and peanuts in the utilization of nutrients and space for growth so that growth and development of maize plants remain optimal. Therefore, it is necessary to conduct research on the population ratio between maize and peanut plants and the frequency of weeding in the intercropping system to obtain high growth and yield of maize. The research objectives were to determine the optimal population ratio at each frequency of weeding to the growth and yield of maize, determine the optimal population ratio in the intercropping system with peanuts to the growth and yield of maize, determine the appropriate frequency of weeding on the growth and yield of maize.

\section{MATERIALS AND METHODS}

\section{Research Implementation}

This research was conducted from February to May 2020 in residential land with ultisol soil types at an altitude of +10 meters above sea level, located in Gang Juwita Kanan 2 Kandang Limun, Muara Bangkahulu District, Bengkulu City.This research was conducted in the form of a field experiment using a completely randomized complete block design (RCBD) to test 2 treatment factors arranged in a split plot design. The first treatment factor is the frequency of weeding as the main plot, namely:

$\mathrm{G}_{0}: 0 \mathrm{x}$ weeding (without weeding)

$\mathrm{G}_{1}: 1 \mathrm{x}$ weeding (21 DAS)

$\mathrm{G}_{2}: 2 \mathrm{x}$ weeding (21 DAS and $42 \mathrm{DAS}$ )

The second treatment factor, the planting density of sweet corn and peanuts as subplots consisted of:

$\mathrm{P}_{1}: 100 \%$ corn $+0 \%$ peanuts

$\mathrm{P}_{2}: 80 \%$ corn $+20 \%$ peanuts

$\mathrm{P}_{3}: 60 \%$ corn $+40 \%$ peanuts

$\mathrm{P}^{4}: 40 \%$ corn $+60 \%$ peanuts

$\mathrm{P}_{5}: 20 \%$ corn $+80 \%$ peanuts

Thus, there were 15 treatment combinations that were repeated 3 times and repeated as a group, so that 45 experimental units were obtained. $100 \%$ population of maize is 50,000 plants per hectare, while $100 \%$ population of peanuts is 200,000 plants per hectare.

\section{Research Stages}

Land preparation is done by clearing the land from weeds using sickles. Soil processing is done manually by hoeing until the soil becomes loose, even, and clean of weeds and plant debris. Then it is made into plots with each size $250 \mathrm{~cm}$ x $200 \mathrm{~cm}$. between mapped in the form of a syringe for drainage. Manure is applied 1 week before planting at a dose of 10 tons per hectare. Manure is weighed using a manual scale according to the dose, then sprinkled on the ground and mixed with the soil evenly using a hoe. The seeds used in this study are the Bisi-18 variety, while the peanut seeds were the Talam 3 variety. The seeds were selected which had the characteristics of normal size, healthy, intact, and had been tested for the viability of $86 \%$ for corn seeds, while peanut seeds were $96 \%$. Planting of corn and peanut seeds are planted simultaneously in alternating rows and evenly distributed with the number of seeds of each type according to treatment. The seeds are inserted into the planting hole, which is made by cutting 1 seed as deep as $3 \mathrm{~cm}$ per hole and adding 5 Carbofuran seeds, then the planting hole is covered with soil. Fertilization is conducted in an array $5 \mathrm{~cm}$ apart from the plant row and then immersed in the soil as deep as $3 \mathrm{~cm}$ when the plants are 14 DAS. The types and doses of fertilizers used are presented in Table 1 below. Plant care which is carried out includes, irrigation is carried out in the morning and evening using well water that is poured using gembor on the plants and the growing media around them. Irrigation is not done when it rains, which makes the soil wet. Weeding is carried out according to the treatment, by pulling out all weeds using a pick and removing them, so that the 
plot of land is clean from weeds. Embroidering is carried out at the age of 7 DAS, by replanting healthy seeds into planting holes where the seeds do not grow or grow abnormally. Chemical control of pests and diseases in corn and peanuts. The attack by the fungus Fusarium sp (leaf blight) on peanut plants is controlled by spraying a fungicide solution made from the active ingredient Mankozeb at a dose of 45 grams/tank of 15 liters. Spraying is done once a week to all parts of the plant. The control of caterpillar and grasshopper pests by spraying an insecticide solution containing the active ingredient Deltamethrin at a dose of $5 \mathrm{~mL} / \mathrm{L}$ to the entire plant at intervals of once a week. Harvesting of maize is carried out after showing the harvest criteria, namely: the cobs or husks begin to dry out. The color of the corn kernels is dark yellow, when the seeds are pressed with a nail it doesn't leave a mark. In addition, the stalks and leaves of the corn have turned yellow and the corn plants are 105 DAS old. Harvesting is done by breaking the cob from the trunk then peeling the cob by removing the cob and then drying it in the sun for 3 days. Cob that has dried, the seeds are flaked. Measurement to obtain data from the research results, observations were made on 5 sample plants in each experimental unit that had been determined randomly. Each sample plant is attached with a marker label which is labeled with the sample code.

The measured variables include, Plant height was measured from the base of the lower stem from the soil surface to the highest leaves by budding using a meter at the age of 3 MST until male flowers appeared at 10 day intervals, namely at 21 DAS, 31 DAS, 41 DAS and 51 DAS. Number of leaves (strands) counted were leaves that had opened perfectly marked by the presence of leaf tongues. Counting the number of leaves started from 21 DAS with an interval of 10 days until flowers appeared, namely at 21 DAS, 31 DAS, 41 DAS and 51 DAS.Leaf area measured can be done using the formula $\mathrm{p}$ x 1 x 0.75 (Susilo, 2015). Measurements are made using a meter by measuring the length of the leaves from the axillary to the tip of the leaves, while the width of the leaves is measured at the middle of the leaf that is the widest. All leaves in the sample plants were measured in the maize hair exit phase (silking), which is when the plants were 55 DAS.The diameter of the stems $(\mathrm{mm})$ was measured at harvest using a digital caliper on the second book from above ground level.The weight of the complete cob (g) was observed by weighing it using digital scales. The weight of the cob (g) was observed by weighing it after the weights were removed using a digital scale.The weight of the shelled seeds $(\mathrm{g})$ of the plant was observed after the seeds were peeled or separated from the cobs and then weighed using a digital scale.The weight of 100 seeds $(\mathrm{g})$ was observed by weighing using a digital scale as many as 100 corn kernels which were taken randomly.Plant fresh weight (grams), the fresh weight of the plant was measured all parts of the plant from the roots to the top of the plant without cobs using digital scales. Previously, the roots of the corn plant were cleaned from the ground using water. Biomass weight (grams) was carried out when the plants were harvested by weighing all parts of the plant except for cobs that had been oven at $80{ }^{\circ} \mathrm{C}$ for up to 48 hours using analytical scales.

\section{Effective root nodules of peanut plants}

Effective nodules were observed in the final vegetative phase when the plants were 40 DAS. The observation of the number of nodules was carried out by digging around the sides of the plant hole to avoid the roots remaining in the soil. Then the roots were cleaned with water first until the soil was released from the roots, then the effective nodules were counted manually with the characteristics of effective nodules attached to a single root and pink when cleaved. The data obtained were analyzed using Analysis of Variance (ANOVA) at a test level of $5 \%$. Data that had a real effect was carried out further tests using the Duncan Multiple Range Test (DMRT) at the test level of 5\%.

\section{RESULTS AND DISCUSSION}

\section{Overview of Research}

The climatic conditions at the research location during the experiment were the amount of rainfall per month, respectively $351 \mathrm{~mm}, 406 \mathrm{~mm}, 366 \mathrm{~mm}$, and 321 $\mathrm{mm}$. The average air temperature is $27.8{ }^{\circ} \mathrm{C}, 27.4{ }^{\circ} \mathrm{C}$, $27.6{ }^{\circ} \mathrm{C}$, and $27.8{ }^{\circ} \mathrm{C}$. The mean relative humidity (RH) of air was $81 \%, 84 \%, 86 \%$, and $84 \%$, respectively, and the sun's irradiation intensity, respectively, $67 \%, 67 \%$, $74 \%$, and $63 \%$. From climate data, it is known that the rainfall that occurs is quite high for the growth of maize plants which requires a minimum rainfall of $8 \mathrm{~mm}$, a maximum of $200 \mathrm{~mm} \mathrm{month}{ }^{-1}$ (Barnito, 2009). The condition of maize plants at 20 DAS experienced abnormal growth where the dwarf maize plants and their leaves turned yellow because some plots in the experimental land were flooded due to heavy rains which caused the soil to compact. This puddle occurs due to poor drainage channels and sedimentation of material (sand) which is carried by the flow of rainwater during heavy rains so that water does not flow into the sewer. This is overcome by repairing water channels between plots and drainage channels and then burying the soil around the plant roots after weeding 21DAS so that the mapped soil is not solid. The drainage channel is repaired every time it rains. After the plants are $30 \mathrm{DAS}$, the maize plants start 
to return to normal and the leaves have started to return to green. When the plants were $18 \mathrm{DAS}$, the corn and peanuts were attacked by the fungus Fusarium sp, namely leaf blight, then sprayed with a fungicide made from the active ingredient Mankozeb at a dose of 45 grams $\operatorname{tank}^{-1}$ of $15 \mathrm{~L}$. Spraying is done once a week by spraying all parts of the plant so that it is not infected. Apart from being attacked by fungus, corn plants are also attacked by caterpillars and grasshoppers that eat the young leaves and shoots, resulting in perforated and irregular plant leaves. Caterpillars and grasshoppers were controlled with an insecticide containing the active ingredient Deltametrin at a dose of $5 \mathrm{~mL} \mathrm{~L}^{-1}$ which was sprayed throughout the plant at intervals of once a week.

\section{Analysis of Variance}

The results of the analysis of the diversity of the growth and yield variable data included: plant height, number of leaves, stem diameter and total leaf area per plant, the weight of cob with weight, the weight of cob without husks, the weight of shelled seeds per plant, the weight of 100 seeds, fresh weight of plants and the summarized biomass weights are presented in Table 1 .

Table 1. Summary of the results of the variance of the effect of population comparisons and frequency weeding the growth and yield of corn in the system

\begin{tabular}{|c|c|c|c|c|}
\hline \multirow[b]{2}{*}{$\begin{array}{l}\text { Variable of } \\
\text { Corn }\end{array}$} & \multicolumn{3}{|c|}{ Ratio of mean squares ( $\mathrm{F}$ value) } & \multirow[b]{2}{*}{$\begin{array}{c}\text { Coefficient } \\
\text { of variance } \\
(\%)\end{array}$} \\
\hline & $\begin{array}{c}\begin{array}{c}\text { Planting } \\
\text { density } \\
(\mathrm{P})\end{array} \\
\end{array}$ & $\begin{array}{c}\begin{array}{c}\text { Frequency } \\
\text { of weeding } \\
\text { (G) }\end{array} \\
\end{array}$ & $\begin{array}{c}\begin{array}{c}\text { Interaction } \\
(\mathrm{G} \times \mathrm{P})\end{array} \\
\end{array}$ & \\
\hline $\begin{array}{l}\text { Plant height } 51 \\
\text { DAS }\end{array}$ & $1.140 \mathrm{~ns}$ & $0.051 \mathrm{~ns}$ & $1.590 \mathrm{~ns}$ & 19.09 \\
\hline $\begin{array}{l}\text { Number of } \\
\text { leaves 51DAS }\end{array}$ & $0.398 \mathrm{~ns}$ & $0.047 \mathrm{~ns}$ & $1.008 \mathrm{~ns}$ & 23.73 \\
\hline $\begin{array}{l}\text { Total leaf area } \\
\text { planted }\end{array}$ & $2.461 \mathrm{~ns}$ & $0.123 \mathrm{~ns}$ & 0.452 ns & 21.02 \\
\hline Rod diameter & $4.959^{* *}$ & $6.806 \mathrm{~ns}$ & $1.320 \mathrm{~ns}$ & $7.79 \%$ \\
\hline Cob weight & $0.663 \mathrm{~ns}$ & $0.108 \mathrm{~ns}$ & $0.661 \mathrm{~ns}$ & $8.85 \%$ \\
\hline $\begin{array}{l}\text { Cob weight } \\
\text { without grind }\end{array}$ & 0.434 ns & $0.072 \mathrm{~ns}$ & $0.519 \mathrm{~ns}$ & $19.46 \%$ \\
\hline $\begin{array}{l}\text { The weight of } \\
\text { the shelled } \\
\text { seeds per plant }\end{array}$ & $0.256 \mathrm{~ns}$ & $0.071 \mathrm{~ns}$ & $1.035 \mathrm{~ns}$ & $17.86 \%$ \\
\hline $\begin{array}{l}\text { Weight of } 100 \\
\text { seeds }\end{array}$ & $0.258 \mathrm{~ns}$ & $0.065 \mathrm{~ns}$ & $1.222 \mathrm{~ns}$ & $10.83 \%$ \\
\hline Plant freshness & $5.890 * *$ & $43.028 * *$ & $0.966 \mathrm{~ns}$ & $7.65 \%$ \\
\hline $\begin{array}{l}\text { Weight of } \\
\text { biomass }\end{array}$ & $5.553 * *$ & $0.920 \mathrm{~ns}$ & $1.070 \mathrm{~ns}$ & $12.46 \%$ \\
\hline F Table & 2.78 & 6.94 & 2.36 & \\
\hline
\end{tabular}

(*) Significantly different, (ns) Not significantly different
The observed variable data for the maize plant being tested had a coefficient of variability ranging from $7.65 \%-23.73 \%$. The lowest value range was on the plant fresh weight variable, while the highest coefficient value for the variable number of leaves was 51 DAS. The coefficient of variance $(\mathrm{CV})$ can be interpreted as a description of the level of population diversity of an experiment. The coefficient of diversity also shows the level of validity of an experiment. The results of the analysis of variance on the observed variables (Table 1) showed that there was no significant interaction between the population ratio and the frequency of weeding for all growth and yield variables of maize. This shows that the response of the growth and yield of maize to the ratio of the population in the intercropping system with groundnut is not affected by the frequency of weeding. In this intercropping system, the maize plant has a higher habitus. This is presumably because the population ratio between the two plants is tight, if the maize population decreases it is offset by an increase in the peanut population. Vice versa, when the maize population increases, the peanut population also decreases. This is related to the growth of weeds that can be suppressed because of the canopy of corn and peanut leaves that cover each other in each treatment which results in sunlight being unable to continue to the weeds that grow underneath so that the plant population ratio does not significantly affect the frequency of weeding. Moenandir (1993) suggests that the presence of intercropping plants in the space between rows is expected to suppress the growth of weeds so that weeds will be controlled indirectly and are expected to reduce competition with the main crop. Arrangement of plant density and population ratio is one way of controlling weeds with a cultivation system. The results of the research by Pujisiswanto \& Hidayat (2008) stated that the population of $75 \%$ peanuts (plant spacing $40 \mathrm{~cm} \times 10$ $\mathrm{cm}$ ) was able to control weeds well compared to other treatments, this was due to the density of the peanut plants so that the incoming sunlight hit the low soil. allows weeds not to grow properly.

In the intercropping system to get a combination of plants, many factors must be considered, especially competition between mixed plants, both for growth and in plant development. In this case, the intercropped plants will have a relationship or are called interactions. There is a competitive interaction, namely when one plant blocks growth or competes with other plants in the utilization of nutrients, water, oxygen, and sunlight. It is complementary, that is, if each plant will grow and produce better than monoculture plants (Wibowo, 2009).

The treatment of planting density and frequency of weeding on stand-alone maize does not affect the two of them. The independent population comparison treatment showed a significant effect on the variables of stem diameter, fresh weight, and weight of biomass, while the other variables had no significant effect. Furthermore, the frequency of weeding has no significant effect on most 
of the growth and yield variables of maize with the weight of streaks, which shows a significant difference.

\section{The Effect of Planting Density on Corn Growth and Yield}

The treatment of planting density that gave significant differences to the growth and yield variables of maize was carried out by the Duncan's Multiple Range Test (DMRT) which was presented in Table 2.

Table 2. Effect of planting density on stem diameter, plant fresh weightand biomass weight

\begin{tabular}{l|l|l|l}
\hline $\begin{array}{l}\text { Planting } \\
\text { density }\end{array}$ & $\begin{array}{l}\text { Stem diameter } \\
(\mathrm{mm})\end{array}$ & $\begin{array}{l}\text { Plant fresh } \\
\text { weight }(\mathrm{g})\end{array}$ & $\begin{array}{l}\text { Weight of } \\
\text { biomass (g) }\end{array}$ \\
\hline $\begin{array}{l}\mathrm{P}_{1: 100 \%} \\
\text { corn }+0 \% \\
\text { peanuts }\end{array}$ & $21.397 \mathrm{~b}$ & $489.044 \mathrm{~b}$ & $63.577 \mathrm{c}$ \\
$\begin{array}{l}\mathrm{P}_{2:}: 80 \% \\
\text { corn }+20 \% \\
\text { peanuts }\end{array}$ & $21.595 \mathrm{~b}$ & $519.267 \mathrm{~b}$ & $71.182 \mathrm{bc}$ \\
$\begin{array}{l}\mathrm{P}_{3:}: 60 \% \\
\text { corn }+40 \% \\
\text { peanuts }\end{array}$ & $22.915 \mathrm{~b}$ & $512.711 \mathrm{~b}$ & $65.544 \mathrm{c}$ \\
$\begin{array}{l}\mathrm{P}_{4:} 40 \% \\
\text { corn }+60 \%\end{array}$ & $24.675 \mathrm{a}$ & $667.511 \mathrm{a}$ & $79.924 \mathrm{a}$ \\
peanuts & & & \\
$\begin{array}{l}\mathrm{P}_{5}: 20 \% \\
\text { corn }+80 \% \\
\text { peanuts }\end{array}$ & $22.877 \mathrm{~b}$ & $543.244 \mathrm{~b}$ & $76.598 \mathrm{ab}$ \\
\hline $\begin{array}{l}\text { The number followed by the same letter in the same colvmn show no } \\
\text { significant difference at the } 5 \% \text { level of DMRT }\end{array}$
\end{tabular}

The diameter of maize stalks in the $\mathrm{P} 4$ population comparison treatment (40\% maize $+60 \%$ peanuts) gave the largest yield $(24.675 \mathrm{~mm})$ compared to other treatments because the spacing between maize plants was wider $(75 \mathrm{~cm}$ x $50 \mathrm{~cm})$. research by Efendi \& Suwardi (2010) states that the more tenuous the maize population can increase the growth of stem diameter, on the contrary, if the dense maize population will suppress the growth of stem diameter. This is also similar to the research of Sarifi et al. (2009) stated that the denser the plant population can reduce the growth of stem diameter.

Based on Table 2 above, it can be seen that the ratio of $\mathrm{P} 4$ population ( $40 \%$ maize $+60 \%$ peanuts) with a spacing of $75 \mathrm{~cm} \times 50 \mathrm{~cm}$ produces the highest plant fresh weight, which is 667.511 grams. This is in line with Widiyono's research (2010) which states that the variable fresh weight of maize gives the highest yield in the population ratio with the widest spacing of $70 \mathrm{~cm} \times 40 \mathrm{~cm}$ compared to other treatments. Similar to the diameter of the maize stalks, the more plant population will provide optimal plant fresh weight as the plant stems grow.

Likewise in plant biomass variables, it can be seen that the ratio of $\mathrm{P} 4$ population ( $40 \%$ maize $+60 \%$ peanuts) with a spacing of $75 \mathrm{~cm} \mathrm{x} 50 \mathrm{~cm}$ gives the highest yield, namely 79.924 grams. x 40 $\mathrm{cm}$ gave the highest biomass yield compared to other treatments. Biomass is the weight of all organisms which is usually expressed in dry weight or unit area, the living material produced by plants that are free from the influence of gravity so that it is constant (Sitompul \& Guritno, 1995). The use of dry weight as a growth observation variable is because the plant's fresh weight fluctuates depending on humidity conditions. Meanwhile, the tissue that has dried up because it has experienced a very large loss of fresh weight, the measured plant weight will be constant. Plant dry weight is the result of photosynthesis, if the dry weight of the plant is known, it can be seen the ability of the plant to produce photosynthate (Goldsworthy \& Fisher, 1992).

Statistically (Table 1) that the planting density has no significant effect on the maize plant variables, namely plant height, number of leaves, total leaf area of the plant, weight of cob with weight, the weight of cob without husk, weight of shelled seeds per crop, and weight of 100 seeds (Table 3 ). However, there is a tendency that the ratio of $\mathrm{P} 4$ population ( $40 \%$ maize $+60 \%$ peanuts) produces a higher average than the ratio of P5 population ( $20 \%$ maize $+80 \%$ peanuts) with the largest population of peanuts.

This is presumably because the peanut plant population at P5 is too dense so that peanuts become a competitor for maize in the utilization of nutrients, water, sunlight, and growing space, although the root system is different the root area is the same. In addition, peanuts are not able to contribute the $\mathrm{N}$ fixation to maize because they are still lacking to meet the needs of the plants themselves so that the peanut plants take nutrients from the soil to compete with corn plants. It can be seen from the low number of effective root nodules of peanut plants ranging from $16.33-47.33$ which affects the anchoring of $\mathrm{N}$ elements from the air. According to Arimurti (2000), Rhizobium's ability to fix nitrogen from the air was influenced by the size of root nodules and the number of root nodules. The bigger the nodule or the more root nodules that form, the more nitrogen that can be fixed.

According to Bakkara (2010), regulating the plant population is an important factor to get maximum results, because the appropriate population regulation will be able to achieve maximum production as well. 
Table 3. Average effect of planting density on plant height $(\mathrm{PH})$, leaf of number (NL), total leaf area total (LA), ear weight (EW), weight of cob without husk (WCNH), seeds weight per plant (SWP), weight of 100 seeds (W100S)

\begin{tabular}{lccccccc}
\hline Planting density & PH $(\mathrm{cm})$ & $\begin{array}{c}\text { NL } \\
(\text { strands })\end{array}$ & $\begin{array}{c}\text { LA } \\
\left(\mathrm{cm}^{2}\right)\end{array}$ & $\begin{array}{c}\text { EW } \\
(\mathrm{g})\end{array}$ & $\begin{array}{c}\text { WCNH } \\
(\mathrm{g})\end{array}$ & $\begin{array}{c}\text { SWP } \\
(\mathrm{g})\end{array}$ & $\begin{array}{c}\text { W100S } \\
(\mathrm{g})\end{array}$ \\
\hline $\begin{array}{l}\text { P1: } 100 \% \text { corn }+0 \% \\
\text { peanuts }\end{array}$ & 188.21 & 9.78 & 5249.65 & 280.58 & 235.67 & 163.89 & 31.07 \\
$\begin{array}{l}\text { P2: } 80 \% \text { corn }+20 \% \\
\text { peanuts }\end{array}$ & 191.46 & 9.76 & 4853.33 & 276.87 & 226.73 & 165.47 & 30.91 \\
$\begin{array}{l}\text { P3: } 60 \% \text { corn }+40 \% \\
\text { peanuts }\end{array}$ & 196.08 & 10.20 & 3781.71 & 266.64 & 226.84 & 155.44 & 31.09 \\
$\begin{array}{l}\text { P4: } 40 \% \text { corn }+60 \% \\
\text { peanuts }\end{array}$ & 200.41 & 10.44 & 5402.35 & 305.29 & 249.93 & 167.44 & 32.18 \\
$\begin{array}{l}\text { P5: } 20 \% \text { corn }+80 \% \\
\text { peanuts }\end{array}$ & 167.29 & 9.16 & 4826.34 & 278.38 & 227.69 & 159.20 & 31.93 \\
\hline
\end{tabular}

The higher the plant population density, the higher the competition between plants for nutrients and light. If the population increase is still below the threshold for crop competition, then an increase in production will be achieved in a denser population. The competition that arises in population comparisons between two types of intercropping plants is a problem that must be considered. The impact of competition on main and intercrops can reduce plant growth and yields compared to monoculture plant growth and the yield of the population ratio is not correct (Zuchri, 2007). According to research by Pasau et al. (2008), the optimal population ratio for intercropping corn and peanuts is $50 \%$ maize ( 40 $\mathrm{cm} \times 80 \mathrm{~cm}$ spacing) and $50 \%$ peanuts $(40 \mathrm{~cm} \mathrm{x} 40$ $\mathrm{cm}$ spacing).

The ratio of the yield of peanut in the intercropping system with corn plants

The yield ratio is the value of the ratio of crop yields in the intercropping system compared to the yields of plants in the monoculture system. The yield ratio value can be used as a basis in determining whether or not a type of plant is suitable for intercropping. The relative yield value can be calculated from the yield data per plant by producing the relative yield value (Ryi), namely the ratio of the yield size of plant i per individual in the intercropping system with the yield of the monoculture. Or with the formula:
Ryi $=($ yij per individual $) /($ yii per individual $)$

Plant type $i$ is suitable for intercropping if the value (Ryi) is $>1$. Thus the yield per individual species in the intercropping system (Yij) is greater than the yield per individual type $i$ in the monoculture system (Yii). This shows that type i plants can benefit from the intercropping of interactions with other types of plants. The relative yield value of plant $i$ per plot (RYi) is the ratio of the yield size of plant $i$ per plot in the intercropping system with the yield of monoculture in the same plot. or with the formula: $\mathrm{RYi}=($ Yij per plot $) /($ Yii per plot $)$. Type $\mathrm{i}$ plants are suitable for intercropping if the ratio of yield per plot $(\mathrm{RYi})>0.5$ The value of yield per plot $(\mathrm{RYi})=$ 0.5 means that the yield of type i plants of 0.5 intercropping is equivalent to the yield of type i plants covering an area of 1 in the monoculture or equivalent to the ratio of the population. (Beets, 1982).

Based on the relative yield value of maize in Table 4, it can be seen that the four population comparisons have relative yield values per corn plant ranging from 0.95 to 1.02 or an average of 0.99 . Meanwhile, the results are almost the same as the population comparison. This shows that in the intercropping system with groundnut plants, corn plants do not benefit from or are not subject to pressure from the existence of peanut plants. 
Table 4. Relative yields of maize

\begin{tabular}{|c|c|c|c|c|}
\hline Planting density & $\begin{array}{l}\text { Weight of corn } \\
\text { kernels / plant } \\
\quad \text { (grams) }\end{array}$ & $\begin{array}{l}\text { Relative yield per } \\
\text { plant of corn }\end{array}$ & $\begin{array}{l}\text { Weight of corn } \\
\text { kernels/plot } \\
\text { (grams) }\end{array}$ & $\begin{array}{l}\text { Relative yield per } \\
\text { plot of corn }(\%)\end{array}$ \\
\hline $\begin{array}{c}\mathrm{P}_{1}: 100 \% \text { corn }+0 \% \\
\text { peanuts }\end{array}$ & 163.89 & 1 & 4097.22 & $100 \%$ \\
\hline $\begin{array}{c}\mathrm{P}_{2}: 80 \% \text { corn }+20 \% \\
\text { peanuts }\end{array}$ & 165.47 & 1.01 & 3309.33 & $81 \%$ \\
\hline $\begin{array}{c}\mathrm{P}_{3}: 60 \% \text { corn }+40 \% \\
\text { peanuts }\end{array}$ & 155.44 & 0.95 & 2331.67 & $57 \%$ \\
\hline $\begin{array}{c}\mathrm{P}_{4}: 40 \% \text { corn }+60 \% \\
\text { peanuts }\end{array}$ & 167.44 & 1.02 & 1674.44 & $41 \%$ \\
\hline $\begin{array}{c}\mathrm{P}_{5}: 20 \% \text { corn }+80 \% \\
\text { peanuts }\end{array}$ & 159.2 & 0.97 & 796 & $19 \%$ \\
\hline
\end{tabular}

The results of the relative value also showed that the maize plant did not compete with peanuts and peanuts. It is assumed that peanuts could support the growth of maize plants. Peanut is a legume plant that can symbiosis with rhizobium which is able to bind free nitrogen in the air and can fertilize the soil (Prasetyo et al., 2009). Intercropping between legume (groundnut) and non-legume (maize) plants is very suitable, because legume plants can binds free $\mathrm{N}$ from the air through the rhizobium in the nodules (Warman \& Kristiana, 2018). In addition, the rate of $\mathrm{N}$ fixation varies according to the stage of plant growth. N-binding activity in the atmosphere until flowering plants are slow, increasing rapidly after flowering and then decreasing after pod formation, and $80 \%$ of nitrogen has been fixed between the flowering stage and the formation of young seeds (Weber et al., 1971 In Kesumawati, 1991)

\section{The Effect of Weeding Frequency on Growth and} Yield of Corn

Plant fresh weight is a frequency treatment of weeding that has a significant effect on the growth and yield variables of maize. Duncan's Multiple Range Test (DMRT) is carried out by the followup test which is presented in Table 5 .

The results of the analysis of plant fresh weight data (Table 1) showed that the frequency of weeding had a significant effect on the fresh weight of maize plants. Weeding frequency 2 times (21 DAS and 42 DAS) gave the highest plant fresh weight, namely 588.08 grams.
Table 5. The effect of weeding frequency on fresh weight of maize plants

Weeding frequency Plant fresh weight $(\mathrm{g})$

\begin{tabular}{ll}
\hline $\mathrm{G}_{0}: 0$ times weeding & $497.78 \mathrm{~b}$ \\
$\mathrm{G}_{1}: 1$ time weeding & $553.20 \mathrm{ab}$ \\
$(21$ DAS) &
\end{tabular}

$\mathrm{G}_{2}: 2$ times weeding (21 DAS and 42 DAS)

588.08 a

The numbers followed by the same letter in the same column show insignificant differences at the 5\% level of DMRT, DAS (Days After Sowing)

According to Dinata et al. (2017), to obtain optimal fresh weight of maize plants it is necessary to weed more than once, namely 21 DAS and 42 DAS. The results of research by Yahfi et al. (2017) also stated that the frequency of weeding 3 times at the age of 15 DAS, 30 DAS and 45 DAS resulted in the highest fresh weight of sorghum plants among other treatments. Furthermore, Fadhilah et al. (2018) stated that the more frequent weeding, the better the growth and yield of corn plants. Weed control carried out at 21 DAS corn was able to increase the growth of 
maize plants due to the presence of weeds in the critical phase of maize growth. Many studies have stated that controlling weeds during the critical period of the crop is the same as controlling weeds throughout the growing period. According to Simamora's research (2008), controlling weeds at 21-28 DAP from maize gave the same results as controlling weeds along the life cycle of maize plants.

The frequency of weeding did not provide a significant difference to the growth and yield variables of maize such as plant height, number of leaves, total leaf area of plants, stem diameter, weight of weighted cob, weight of cob without husk, weight of shelled seeds and weight of biomass, but there was a tendency that at 2 times weeding frequency (21 DAS and 42 DAS) the average yield was higher than 1 time weeding (21 DAS) and without weeding gave a low average. This is because the treatment without weeding cannot control weeds in the critical period phase of the maize plant, causing high competition between plants and weeds. According to Sena et al. (2018), the high competition between plants and weeds will result in plants growing not optimally due to limited space to grow and the struggle for nutrients. Limited space to grow can also result in disruption of root development in absorption of elements and water in the soil. Mayadewi (2007) states that crop yields will decrease if there are weeds that grow above the tolerance threshold. The presence of these weeds can harm nearby staple crops. This is because weeds generally have high competitive power, so that their presence in the plantations must be controlled through weeding in the right time and frequency.

\section{CONCLUSIONS}

Based on the results and discussion of the research, it can be concluded as follows:

The growth and yield of maize in the tumpasari system with peanuts gave the same response to the population ratio at all weeding frequencies. The comparison of the population $(40 \%$ corn $+60 \%$ peanuts) gave the highest yield on the variable stem diameter of $24.675 \mathrm{~mm}$, plant fresh weight with a weight of 667.51 grams and biomass weight with a weight of 79.924 grams. The relative yield per individual of maize in the peanut intercropping system of 1 indicates that the maize plant does not gain or lose in interacting with peanuts. Thus, corn can be intercropped with groundnut. The proper treatment of weeding frequency on the growth and yield of maize was twice weeding frequency (21 DAS and 42 DAS) with the highest yield on plant fresh weight variable of 588.08 grams.

Table 6.Average figures of the influence of the frequency of weeding on the growth and yield of maize

\begin{tabular}{lccccccccc}
\hline $\begin{array}{l}\text { Weeding } \\
\text { frequency }\end{array}$ & PH $(\mathrm{cm})$ & $\begin{array}{c}\text { NL } \\
(\text { strands })\end{array}$ & $\begin{array}{c}\text { LA } \\
\left(\mathrm{cm}^{2}\right)\end{array}$ & $\begin{array}{c}\text { SD } \\
(\mathrm{mm})\end{array}$ & $\begin{array}{c}\text { CW } \\
(\mathrm{g})\end{array}$ & $\begin{array}{c}\text { EW } \\
(\mathrm{g})\end{array}$ & $\begin{array}{c}\text { SWP } \\
(\mathrm{g})\end{array}$ & $\begin{array}{c}\text { W100S } \\
(\mathrm{g})\end{array}$ & $\begin{array}{c}\text { BW } \\
(\mathrm{g})\end{array}$ \\
\hline $\mathrm{G}_{0}$ : No weeding & 184.65 & 9.68 & 4909.99 & 21.71 & 275.03 & 229.78 & 160.28 & 31.04 & 69.95 \\
$\mathrm{G}_{1}:$ 1x weeding & 188.19 & 9.81 & 5147.86 & 22.64 & 281.47 & 231.21 & 159.56 & 31.89 & 71.34 \\
$\begin{array}{l}21 \text { DAP), } \\
\mathrm{G}_{2}: \text { 2x weeding }\end{array}$ & & & & & & & & & \\
$(21$ DAP and 42 & 193.22 & 10.11 & 5166.51 & 23.71 & 288.16 & 239.12 & 167.03 & 31.37 & 72.80 \\
DAP & & & & & & & & & \\
\hline
\end{tabular}

DAP (Day After Planting), plant height (PH), number of leaves (NL), total leaf area (LA), stem diameter (SD) (mm), cob weight $(\mathrm{CW})$, ear weight (EW), seeds weight per plant (SWP), weight of 100 seeds per plant (W100S), weight of biomass (BW) 


\section{References}

Bakkara, J. C. (2010). Tanggap Pertumbuhan dan Produksi Jagung (Zea mays L.) Varietas Pioneer 23 terhadap Sistem Populasi dan Jumlah Tanaman per Lubang Tanam. Skripsi. Fakultas Pertanian Universitas Sumatera Utara, Medan.

Barnito, N. (2009). Budidaya Tanaman Jagung. Suka Abadi, Yogyakata.

Beets, W.C. (1982). Multiple Cropping and Tropical Farming Systems. Gower Publishing Co.

Dinata, A., Sudiarso \& Sebayang, H. T. (2017). Pengaruh waktu dan metode pengendalian gulma terhadap pertumbuhan dan hasil tanaman jagung (Zea mays L.). Jurnal Produksi Tanaman, 5(2), 191197.

Efendi, R \& Suwardi. (2010). Respon Tanaman Jagung Hibrida terhadap Tingkat Takaran Pemberian Nitrogen dan Kepadatan Populasi. Balai Penelitian Tanaman Serealia, Maros Sulawesi Selatan.

Fadhillah, G. I., Baskara, M. \& Sebayang, H. T. (2018). Pengaruh waktu pengendalian gulma pada monokultur dan tumpang sari tanaman jagung (Zea mays L.) dan kacang tanah (Arachis hypogea L.). Jurnal Produksi Tanaman, 6(1), 3846.

Goldsworthy, P. R \& Fisher, N. (1992). Fisologi Tanaman Budidaya Tropik. Gadjah Mada University Press., Yogyakarta.

Hardiman, T., Islami, T. \& Sebayang, H. T. (2014). Pengaruh waktu penyiangan gulma pada sistem tanam tumpangsari kacang tanah (Arachis hypogaea L.) dengan ubi kayu (Manihot esculenta crantz.). J. Produksi Tanaman, 2(2), 111-120.

Kementerian Pertanian. (2020). Laporan Tahunan Badan Ketahanan Pangan Tahun 2019. Jakarta (ID): http://bkp.pertanian.go.id/storage/app/ media/Bahan\% 202020/Laporan\%20Tahunan $\% 20 B K P \% 202019 . p d f$.

Mayadewi, N.N.A. (2007). Pengaruh jenis pupuk kandang dan jarak tanam terhadap pertumbuhan gulma dan hasil jagung manis. J. Agritrop, 26(4),153159.

Moenandir, J. (1993). Persaingan Tanaman Budidaya Dengan Gulma. PT Raja Grafindo Persada, Jakarta.

Nurmas, A. (2011). Pengaturan pola tanam tumpangsari terhadap hasil produksi jagung manis. $J$. Agroteknos, 1(2), 89-95.
Pasau, P., Yudono, P. \& Syukur, A. (2008). Pergeseran komposisi gulma pada perbedaan proporsi populasi jagung dan kacang tanah dalam tumpang sari pada regosol Sleman. Jurnal Ilmu Pertanian, 16(2), 60-78.

Prasetyo, Sukardjo, E.I. \& Pujiwati, H. (2009). Produktifitas lahan dan NKL pada tumpangsari jarak pagar dengan tanaman pangan. J. Akta Agrosia, 12(1), 51-55.

Pujisiswanto, H. \& Hidayat, K. F. (2008). Analisis pertumbuhan gulma, tanaman, dan Hasil jagung dengan berbagai populasi kacang tanah dan kacang hijau dalam sistem tumpangsari. Jurusan Budidaya Pertanian Fakultas Pertanian. Universitas Lampung, Bandar Lampung.

Ratri, Soelistyono, C. H., R. \& Aini, N. (2015). Pengaruh waktu tanam bawang prei (Allium porum L.) pada sistem tumpangsari terhadap pertumbuhan dan hasil tanaman jagung manis (Zea mays saccharata). J. Produksi Tanaman, 3(5), 406-412.

Sarifi R. S., Sedghi, M. \& Gholipouri, A. (2009). Effect of population density on yield attributes of maize hybrids. Res.Jour. Bio. Sci., 4 (4), 375-379.

Sena, E. A., Sebayang, H. T. \& Nugroho, A. (2018). Pengaruh waktu penyiangan pada tumpangsari jagung (Zea mays) dan kacang tanah (Arachis hypogaea L.). J. Produksi Tanaman, 6(9), 2085-2093.

Setiawan, E. (2009). Kearifan lokal pola tanam tumpangsari di Jawa Timur.Agrovigor,2(2),7988.

Sitompul, S. M. \& Guritno, B. (1995). Analisis Pertumbuhan Tanaman. Gadjah Mada University Press., Yogyakarta.

Suarni \& Yasin, M. (2011). Jagung sebagai sumber pangan fungsional. Iptek Tanam Pangan, 6(1), 41-56.

Warman, G. R. \& Kristiana, R. (2018). Mengkaji sistem tanam tumpangsari tanaman semusim. Proceeding Biology Education Conference, 15 (1), 791-794.

Wibowo. (2009). Teknik tumpangsari kedelai pada musim penghujan. Bioedukasi, 2(2), 199-212.

Zuchri, A. (2007). Optimalisasi hasil tanaman kacang tanah dan jagung dalam tumpangsari melalui pengaturan baris tanam dan perompesan daun jagung. J. Embryo, 4(2), 156-163. 